\title{
Listy o aspekcie
}

Pamięci Profesora Stanisława Karolaka

Artykuł oparty jest na korespondencji autorki z Profesorem Stanisławem Karolakiem dotyczącej roli mechanizmów pragmatycznych, takich jak siła illokucyjna przy wyborze aspektu czasownika. Według autorki wybór formy dokonanej związany jest $\mathrm{z}$ fokalizacją siły illokucyjnej na części znaczenia czasownika wyrażającej zmianę i jej rezultat. Dlatego też jeżeli siła illokucyjna skierowana jest na inne części znaczenia czasownika, fakty dokonane wyrażane są przez formę niedokonaną. Stanisław Karolak w swoich listach wyraża odmienną opinię, mianowicie zalicza on asercję do sfery semantyki $\mathrm{i}$ jest przeciwny temu, by brać pod uwagę mechanizmy pragmatyczne w opisie funkcjonowania aspektu.

\section{Aspekt a siła illokucyjna}

Przyczynek dedykowany pamięci Profesora Stanisława Karolaka wypada mi poświęcić kwestiom związanym $\mathrm{z}$ aspektem czasownika, jako że jest to problem, o którym dyskutowaliśmy od wielu lat, bodajże od samego początku naszej znajomości. Obydwoje zgadzaliśmy się oczywiście co do tego, że aspekt zależy od semantyki czasownika i że w naszych modelach aspektu jest to podstawowy punkt wyjścia, który zresztą od dawna jest ogólnie przyjęty przez językoznawców zajmujących się tą kategorią. Różniła nas natomiast opinia dotycząca roli pragmatyki przy wyborze formy dokonanej bądź niedokonanej czasownika. 
Mimo że już pisałam o tej różnicy w artykule poświęconym naszym dwóm wizjom funkcjonowania aspektu (Gebert 1997), chciałabym przytoczyć tu dodatkowe argumenty i przemyślenia, zwłaszcza że w ciągu ostatnich lat mieliśmy okazję ze Stanisławem Karolakiem wymieniać korespondencyjne uwagi na ten temat. Uwagi te dotyczą mojego artykułu (Gebert 2004) poświęconego czynnikom pragmatycznym, które odgrywają rolę w wyborze aspektu. Pisałam tam, że w moim pojęciu do takich ważnych czynników należy mechanizm siły illokucyjnej. Jest to termin zdefiniowany w teorii aktów lingwistycznych przez Austina (Austin 1962), udoskonalony następnie przez Searle'a (Searle 1969), odnoszący się do funkcji komunikatywnej zdania w kontekście, w którym owo zdanie jest wypowiedziane. W ramach takiej wizji każde zdanie ma też siłę illokucyjną, może ona być wyrażona przez asercję, pytanie czy też żądanie, rozkaz, radę, przyrzeczenie itd. Funkcje te mogą być realizowane $\mathrm{w}$ językach w różny sposób: na poziomie gramatycznym bądź segmentalnym, jak również przez prozodię (czyli intonację bądź też akcent kontrastywny). Siła illokucyjna może być sfokalizowana na różnych częściach zdania (1), co pokazują przykłady (2-4) z asercją negatywną, w których negacja dotyczy różnych składników, jak wynika z kontekstu $\mathrm{w}$ nawiasie:

(1) Wczoraj w tym sklepie Jan kupowat papierosy.

(2) Wczoraj w tym sklepie Jan nie kupowat papierosów (tylko owoce).

(3) Wczoraj w tym sklepie nie Jan kupowat papierosy (ale ktoś inny).

(4) Wczoraj w tym sklepie Jan nie kupit papierosów (tylko je znalazt).

Natomiast w przykładach (5) i (6) asercja negatywna jest sfokalizowana na różnych elementach znaczenia czasownika, co przejawia się w zróżnicowaniu aspektowym:

(5) Jan nie kupit papierosów.

(6) Jan nie kupowat papierosów.

W zdaniu (5) negacja skoncentrowana na rezultacie zdarzenia, o którym mowa (Jan nie ma papierosów), pociąga za sobą użycie aspektu dokonanego. W zdaniu (6) natomiast aspekt niedokonany sygnalizuje fakt, że negacja odnosi się do procesu prowadzącego do rezultatu zdarzenia, co implikuje również negację rezultatu, który tym samym nie zaistniał. Tak więc (6) może być sparafrazowane przez (7):

(7) Jan nie próbowat kupić papierosów.

Zdania takie jak (6) ilustrują tzw. użycie ogólnofaktywne aspektu niedokonanego, które stanowi bodaj „najtwardszy orzech do zgryzienia” w całej aspektologii, chodzi tu bowiem o wyjaśnienie znaczenia dokonanego for- 
my niedokonanej. Mamy tu zatem do czynienia ze zdarzeniem zakończonym i dokonanym w przeszłości, a mimo to wyrażonym w przykładach (6) i (8) formą niedokonaną:

(8) a. Wiem, że Jan czytał zadane lektury.

b. Czytałam twój list i nic nie rozumiem. czy też:

(9) a. Wiem, że Jan przeczytał zadane lektury.

b. Przeczytałam twój list $i$ nic nie rozumiem.

Innymi słowy, w obydwu wypadkach chodzi o to, że w przykładach (a) Jan wykonał, co do niego należy i lektury ma przeczytane, a w (b), że ja zapoznałam się z treścią listu.

Wydaje mi się, że jeżeli chce się zdać sprawę z mechanizmu, który decyduje o wyborze między (8) a (9), nie można się obejść bez pragmatyki, czemu dałam wyraz we wspomnianym artykule, opartym na materiale języka rosyjskiego (Gebert 2004).

\section{Wymiana korespondencji}

Na taką propozycję Stanisław Karolak zareagował następującym listem ${ }^{1}$ : „(...) Zasiadłem natychmiast do lektury Twego artykułu i oto kilka refleksji na interesujący Cię temat:

1) nie sprzeczajmy się o nazewnictwo. Jeżeli ktoś chce, może sobie nazywać forza illocutiva (czyli asercję, tzn. predykat prawdy i wymienne $\mathrm{z}$ nim paradygmatycznie predykaty illokutywne) pragmatyką. Ale to tylko kwestia nazewnictwa. Umówmy się zatem, że będziemy mówili o asercji jako o konstytutywym składniku zdania oznajmującego bez tych dodatkowych kwalifikacji;

2) po to, aby pod asercją znalazł się jakiś składnik zdania lub semantyczny składnik czasownika, musi on - używając Twojej terminologii - być najwyżej położonym składnikiem struktury semantycznej. $Z$ tego wynika, że różnicy należy szukać w układzie składników semantycznych, a więc w samych faktach wkładanych w zasięg asercji, a nie w manipulacji asercją. Konkretnie różnicę między interesującą Cię opozycją między użyciem czasowników dokonanych i niedokonanych (tych ostatnich zwłaszcza w tzw. znaczeniu ogólnofaktywnym) należy od-

${ }^{1}$ List jest datowany: Sopot 23.11.2004. Pozwoliłam sobie na podanie dyskutowanych przykładów kursywą dla ułatwienia lektury. 
naleźć $\mathrm{w}$ aspektualnej strukturze verbum. Wielokrotnie pisałem, że w czasownikach dokonanych typu inchoatiwów i rezultatiwów, np. rozstrzygnąć, otworzyć, zbudować, zabić, otruć, zjeść i in., składnikiem najwyżej położonym jest dokonaność prosta (stać się), ewentualnie łącznie z wykładnikiem stanu rezultatywnego i on, ów składnik, musi znajdować się pod asercją. Pozostałe składniki są mu podrzędne, a składnik czynnościowy czy procesualny ma w nim w ogóle charakter adiunktywny. Por. przyjechał vs przyszed $=$ stało się tak, że jest (w wyniku jazdy lub marszu).

Inna jest struktura układu czasowników niedokonanych (tzw. parnych). W nich składnikiem najwyżej położonym jest niedokonaność prosta (dziać się) i ona musi znajdować się pod asercją, a zwłaszcza składnik rezultatywny, który ma charakter czysto potencjalny.

W przypadku tzw. znaczenia ogólnofaktywnego, które dotyczy tylko czasowników niedokonanych w praeteritum, pod asercją znajduje się niedokonaność prosta łącznie $\mathrm{z}$ dokonanością, która oznacza granicę czynności (predel), a więc całość przypomina (jeśli nie jest tożsama) ze złożonym aspektem limitatywnym mającym dominantę dokonaną. Formalnie wykładnikiem owej granicy (predela) czynności czy procesu jest forma czasu przeszłego czasownika (ewentualnie dodatkowe okoliczniki w zdaniu). W przypadku omawianych par mamy więc do czynienia (oczywiście w płaszczyźnie semantycznej) z dwoma aspektami złożonymi, jeden $z$ asercją na zaistnieniu stanu, drugi $z$ asercją na ograniczeniu czynności.

Ten ostatni jest neutralny względem rezultatu, tzn. że w obiektywnej rzeczywistości rezultat może istnieć, ale nie jest składnikiem komunikowanym. Por.:

Eto ja stroil etot most (oczywiście rezultat może być, ale też może go nie być, kiedy np. most został zniszczony).

Eto ja postroil etot most.

Rzecz oczywista, że oprócz obiektywnej (ale nie komunikowanej) obecności rezultatu, por.:

Ja nie jadłem tych owoców (są zjedzone).

Ja nie zjadłem tych owoców.

neutralność aspektu niedokonanego (ogólnofaktywnego) wobec rezultatu pozwala także na użycie czasownika niedokonanego w przypadku jego anulowania, np.:

Kto-to zdes' otkryval okno (kiedy okno jest zamknięte, ale są zauważalne ślady tego, że było otwierane).

K tebe prichodil tovarišč (kiedy już sobie poszedł).

Dotyczy to także przypadków tzw. obratnogo dejstvija. 
I dodałbym jeszcze, że asercja nie odnosi się dodatkowo do „una qualunque altra porzione del significato della frase" ${ }^{2}$. W obu aspektach zdanie pytajne, które cytujesz, dotyczy agensa:

On otkryval okno (ili kto-to drugoj)?

On otkryl okno (ili kto-to drugoj)?

Gdyby ktoś miał wątpliwości (ale chyba nie Ty, bo piszesz, że forma niedokonana „denota i fatti compiuti nel passato", s. 224) co do tego, czy forma niedokonana oznacza (semantyczny) aspekt dokonany - w mojej wersji: konfigurację $\mathrm{z}$ dominantą niedokonaną, czyli złożony aspekt dokonany, zwrócę uwagę na fakt, że w języku bułgarskim, który jest bardziej eksplicytny, odpowiada jej najczęściej perfectum niedokonane lub rzadziej aoryst niedokonany, a więc zawierają w swojej jawnej strukturze składnik dokonany (perfectum $=$ forma dokonaności, aoryst $=$ forma dokonaności).

Nie wiem, czy moja argumentacja jest dla Ciebie dostatecznie przekonująca, ale powinnaś przynajmniej uznać, że dobrze zdaje sprawę z opozycji, o której piszesz w oparciu o fakty sa mego jęz yka bez uciekania się do pozajęzykowych „contratti pragmatici” ${ }^{\text {i }}$ samowolnego manipulowania asercją".

W liście tym wydaje mi się interesujący fakt, że Autor zgadza się z proponowanym przeze mnie uznaniem asercji za czynnik decydujący o wyborze formy dokonanej bądź niedokonanej aspektu. Zasadnicza różnica polega na tym, że w pojęciu Stanisława Karolaka asercja była częścią semantyki, a nie pragmatyki, jak to widzę ja. Oczywiście obydwoje zgadzaliśmy się co do tego, że w pierwszym rzędzie „możliwości aspektowe” czasownika zależą właśnie od semantyki. Ja jednak uważałam, że udział w wyborze aspektu ma również pragmatyka decydująca o fokalizacji asercji (będącej jednym $z$ aktów mowy - speech acts - należących do sfery pragmatyki) na różnych częściach znaczenia, co uwidacznia test $\mathrm{z}$ negacją.

Kontynuując dyskusję na temat statusu form ogólnofaktywnych, w odpowiedzi na przytoczony tu list napisałam ${ }^{5}$ :

„Jestem Ci bardzo bardzo wdzięczna za przeczytanie i komentarz do mojego artykułu.

${ }^{2}$ Cytat z mojego artykułu (Gebert 2004): „jakiejkolwiek innej części znaczenia zdania”.

3 Czyli „odnosi się do faktów dokonanych w przeszłości”.

4 „Kontraktów pragmatycznych” - termin wprowadzony przez Israeli 1996, do którego nawiązuję w Gebert 2004.

${ }^{5}$ E-mail z 27.12.2004. 
Ja oczywiście wiem, jak Ty traktujesz użycia ogólnofaktywne, ale moje pytanie było chyba źle sformułowane. To, co mnie nie zadowala w Twojej analizie tych użyć, to brak możliwości predykcji (przewidzenia) warunków, w których może być użyta forma dokonana bądź niedokonana ogólnofaktywna. Od czego to użycie zależy, czyli czym się różnią zdania:

On już rozwiązał to zadanie / On już rozwiąywał to zadanie?

Przecież nie możemy ich używać dowolnie. Chciałabym zrozumieć, jak byś potraktował ten problem w Twojej teorii właśnie dlatego, że unikasz odniesienia do pragmatyki (czyli warunków wynikających z sytuacji, w jakich jedna lub druga forma mogą być użyte: asercja lub brak takowej w obliczu braku rezultatu). Notabene, w Twoich pracach aspektowych nie spotkałam się z terminem asercja (mówisz o dominancie), którego używasz w liście do mnie, co mnie cieszy, bo wydaje mi się, że bez niej się nie obejdziemy. W zdaniach, które cytujesz:

Ja nie jadłem tych owoców (są zjedzone).

Ja nie zjadłem tych owoców.

negacja (czyli asercja) odnosi się w pierwszym $\mathrm{z}$ nich do agensa (to nie ja je jadłem, chociaż są zjedzone), a w drugim do rezultatu.

Co do fokalizacji asercji na różnych składnikach zdania, to owszem, w przykładach, które cytujesz, odnosi się ona do agensa (i wówczas mamy formę niedokonaną). Ale tam, gdzie asercja nie odnosi się do rezultatu, może przecież dotyczyć samego komponentu kauzacji (np. On nigdy nie rozwiązywał takich zadań). Wydaje mi się, że w tym zdaniu negacja nie dotyczy agensa.

A przykład asercji odniesionej do jeszcze innego składnika zdania to:

Świetnie odpoczęliśmy w tym roku na wakacjach.

A gdzie odpoczywaliście? (a nie: odpoczęliście bo tu asercja / pytanie dotyczy: $g d z i e$ ).

Staszku, czy wówczas, kiedy piszesz do mnie à propos zdania: Ja stroil etot most i dodajesz, że można tak powiedzieć w sytuacji, w której „rezultat może być, ale też może go nie być, kiedy np. most został zniszczony” (cytat z Ciebie), to czy nie odwołujesz się tu do pragmatyki? I czy nie „zatrąca” pragmatyką to, co piszesz chwilę przedtem: „(...) w obiektywnej rzeczywistości rezultat może istnieć, ale nie jest składnikiem komu nikowany m" [podkr. moje]. Czy żeby zdać sprawę z takich przypadków, nie jest niezbędne brać pod uwagę kontekst i sytuację?

Do moich pytań dochodzi jeszcze jedno: dlaczego forma ogólnofaktywna jest oddawana przez formę niedokonaną czasownika i co ona ma wspólnego z innymi użyciami czasowników niedokonanych? Czy zgodzisz się, że wspólnym mianownikiem jest brak asercji na rezultacie?

Bardzo ciekawe są oczywiście dane macedońsko-bułgarskie i to, że te języki mają system czasowy podobny do romańskich (nie biorę pod uwagę 
aspektu ani imperceptywu) i w pewnym sensie też podobnie do romańskich działa w nich aspekt „accompli” (poza tym, że nakłada się systematycznie na czas).

Jednym słowem, Staszku, chodzi mi o to, że myśląc dużo o Twoim modelu, który jest taki koherentny i elegancki, brak mi w nim takiej odpowiedzi na moje pytania, która by pozwolila sformułować operatywne reguły użycia form ogólnofaktywnych, np. w podręczniku dla cudzoziemców”.

Moje uwagi i pytania wywołały kolejną reakcję Stanisława Karolaka ${ }^{6}$ :

„Z Twego listu wynika, że się nieco mijamy w naszych analizach. Dla mnie głównym problemem jest ZNACZENIE, które determinuje użycia i w którego kadrze różne użycia muszą się mieścić. Natomiast, jeśli Cię dobrze rozumiem, dla Ciebie ważniejsze są użycia, stąd tak silny akcent kładziesz na pragmatykę. Bo istotnie użycia to relacje między mówiącym, sytuacją, do której odsyła (czyli ekstensją), a strukturą pojęciową (znaczeniem). Z różnicy ZNACZENIA, a więc z semantyki, a nie z pragmatyki wynika fakt, że zdań typu:

\section{On już rozwiązał to zadanie.}

On już rozwiązywat to zadanie.

„nie możemy używać dowolnie” ani też wymiennie jako równoważne. Zdanie pierwsze to zdanie dokonane rezultatywne, drugie też jest semantycznie dokonane i ma charakter limitatywny z ewentualnym dodatkowym znaczeniem perfektowym. Asercja pada na zamkniętą czynność w abstrakcji od rezultatu. Jest to jak gdyby terminatywna teliczność. Jeśli tych zdań można używać także w sytuacjach pozajęzykowych, w których rezultat jest dany, to dzieje się tak dlatego, że abstrahując od rezultatu, znaczenie jest względem niego neutralne: rezultatu nie komunikuje, ale nie jest sprzeczne $\mathrm{z}$ sytuacją rezultatywną.

W ramach tego znaczenia, podobnie jak i innych, działa struktura tematyczno-rematyczna, która się na nie nakłada, a więc rematem może być, zgodnie $\mathrm{z}$ ogólnymi regułami, treść czasownika lub treść jednego $\mathrm{z}$ aktantów (agens, patiens, miejsce i in.). Ale tę samą strukturę T-R mogą, również zgodnie z ogólną regułą, mieć zdania rezultatywne, np. asercja na agensie:

Ja tego nie zniszczyłem (musiał zniszczyć lub zniszczył ktoś inny).

Więc różnica jest nie tu, lecz $\mathrm{w}$ immanentnym znaczeniu formy werbalnej. W liście do Ciebie pisałem o asercji, mając na uwadze tylko sytuacje, kiedy pod asercją jest czasownik, a nie inny składnik zdania, aby udobit-

${ }^{6}$ E-mail ze stycznia $2005 \mathrm{r}$. 
nić fakt, że w każdym z dwóch omawianych zdań stwierdza się różne rzeczy, w szczególności, że w zdaniu ogólnofaktywnym asercja jest na interwale objętym czynnością, a nie na rezultacie, jak słusznie zauważasz. Żeby uniknąć wszelkich nieporozumień, jeszcze raz podkreślam, że różne odniesienia zdań do rzeczywistości, czyli różne możliwe (dopuszczalne przez znaczenie) użycia, to pewnie istotnie kwestia pragmatyki (tak jak z tym przykładowym zburzonym mostem). Ale to wszystko jest dozwolone lub niedozwolone przez pojęciową wartość formy”.

W odpowiedzi napisałam:

„(...) Tak, mój punkt widzenia jest pragmatyczny (ale i semantyczny, jak wiesz), bo wydaje mi się, że teoria musi mieć też charakter predyktywny, tzn. być w stanie przewidzieć, kiedy się używa jednej formy, a kiedy drugiej; mam na myśli cały czas formę ogólnofaktywną z jednej strony i dokonaną z drugiej (tak jak np. możesz przewidzieć, że czasowniki stanowe czy czynnościowe $\mathrm{w}$ połączeniu $\mathrm{z}$ dokonanością dają konfigurację inchoatywną).

Z asercji nie chcę zrezygnować, bo wydaje mi się, że można uznać, iż obejmuje ona zarówno rezultat, jak i agensa w przykładach takich jak ten, który podajesz:

Ja tego nie zniszczyłem (musiał zniszczyć ktoś inny).

Natomiast:

Ja tego nie niszczylem (musiał zniszczyć ktoś inny)

to asercja sfokalizowana tylko na agensie. W przypadku pierwszym asercja, która się przejawia jako negacja, operuje zarówno na agensie, jak na rezultacie. Ty sam zresztą przyjmujesz możliwość więcej niż jednego elementu pod asercją, kiedy piszesz w Twoim pierwszym liście do mnie: „W przypadku tzw. znaczenia ogólnofaktywnego, które dotyczy tylko czasownikow niedokonanych w praeteritum, pod asercją znajduje się niedokonaność prosta łącznie z dokonanością".

Mechanizm fokalizacji asercji na różnych komponentach zdania przydaje mi się, żeby zdać sprawę z tego, czym kieruje się mówiący, kiedy wybiera jedną lub drugą formę (dokonaność morfologiczna bądź to, co nazywasz dokonanością semantyczną). Wydaje mi się, że jeszcze wyraźniej to widać w imperatywie ${ }^{7}$.

Mój problem z użyciami wynika też z tego, że muszę tę teorię zastosować do nauczania aspektu cudzoziemców.

7 Por. (a) Zjedz tę zupę! vs (b) Jedz tę zupę! W zdaniu (a) siła illokucyjna pada na rezultat: 'chcę, żeby zupa była zjedzona', natomiast w zdaniu (b) na rozpoczęcie czynności lub też na jej kontynuację. 
W każdym razie przykłady bułgarskie z perfektum i aorystem niedokonanym są bardzo ciekawe i, powiedziałabym, pocieszające w całej kwestii ogólnofaktywnej".

\section{Asercja, semantyka a pragmatyka}

W historii badań nad aspektem wielu autorów w kwestii wyboru jednego $\mathrm{z}$ dwóch aspektów bierze pod uwagę istnienie mechanizmów, które odpowiadają poniekąd proponowanej tu sile illokucyjnej, mimo iż niektórzy z nich ograniczają się do stwierdzeń raczej intuicyjnych. Widoczne jest to na przykład u Karcevskiego (Karcevski 1927), kiedy pisze: „la perfectivation d’un procès n'est autre chose que la concentration de notre attention sur l'un des moments concrets du procès à l'exclusion des autres" ("perfektywizacja procesu to nic innego jak koncentracja naszej uwagi na jednym $z$ konkretnych momentów tego procesu, wyłączając zeń inne’). Niezbyt sprecyzowany termin Karcevskiego „koncentracja uwagi” wydaje się odwoływać do czegoś, co mogłoby być podciągnięte pod siłę illokucyjną, asercję, w dzisiejszej terminologii językoznawczej. Również Townsend, slawista amerykański, opisując znaczenie form niedokonanych czasownika odnoszących się do faktów dokonanych w językach słowiańskich, mówi o „shifts of emphases away from the result" ('odsunięcie emfazy od rezultatu'; Townsend 1985a, 286).

Podobne stwierdzenie można znaleźć w pracy Stoll $(2000,110)$ : „If the goal is to defocus the result of an action, the imperfective has to be used" ('Jeżeli ma się na celu defoka lizację rezultatu, należy użyć formy niedokonanej' - podkr. L. G.). Stoll jednak ogranicza się do wyrażenia tej intuicji, nie pogłębiając jej w swojej pracy poświęconej nabywaniu aspektu czasownika przez dzieci rosyjskie.

Kilka lat temu również Padučeva $(2001,11)$ pisała w odniesieniu do czasowników rezultatywnych, co następuje: „Глаголы СВ и НСВ приписываюут ситуации разные концепты, причем различие сводится к с ме ще н и ю о куса в н и м а н и я. Глагол СВ ставит в центр Результат, а деятельность с ее участниками и способом, отходит на задний план, в фон. В фокусе внимания деятельность, а Результат присутствует лишь в виде Цели, на которую направлена деятельность” (“Czasowniki dokonane i niedokonane przypisują sytuacji różne pojęcia, przy czym różnica sprowadza się do przesunięcia fo kusu uwagi. Dla czasownika dokonanego w centrum znajduje się Rezultat, a czynność, jej uczestnicy i sposób przechodzą na drugi plan, czyli tło. Dla czasownika niedokonanego w centrum uwagi znajduje się czynność, a Rezultat obecny jest w nim tylko jako Cel, na który czynność jest skierowana’ - podkr. L. G.). 
Koreański lingwista Chong (2003) analizuje rolę siły illokucyjnej bardziej systematycznie. Nieprzypadkowo to badacz koreański dokonuje analizy aspektu czasownika rosyjskiego z punktu widzenia aktów mowy, zważywszy, że jego język ojczysty dysponuje wieloma wykładnikami siły illokucyjnej, wyrażonymi segmentalnie za pomocą odpowiednich partykuł. Chong uważa, że rosyjski wyraża siłę illokucyjną, posługując się nie tylko środkami prozodycznymi, takimi jak akcent i intonacja, ale również przez opozycję aspektową. W jego mniemaniu aspekt niedokonany jest wyrazem „osłabionej” siły illokucyjnej, podczas gdy aspekt dokonany wyraża siłę illokucyjną „wzmocnioną”.

Tego typu refleksje należą do sfery, którą nazwać by można „mikropragmatyką". W ogromnie bogatej literaturze aspektologicznej można zauważyć ogólną, systematyczną tendencję do rozszerzania analizy lingwistycznej od morfologii, przez składnię i semantykę, aż do mechanizmów tekstowych i makropragmatyki. Tego rodzaju podejście znajdujemy na przykład w artykułach Aliny Kreisberg poświęconych formie ogólnofaktywnej (Kreisberg 1997; 2007). Do struktury tekstu odwołują się też autorzy ciekawej pracy zbiorowej Verbal Aspect in Discourse pod redakcją Nilsa Thelina, opartej na językach nie tylko słowiańskich (Thelin 1990).

Tak więc wśród wielu lingwistów istnieje dzisiaj przeświadczenie, iż aby zdać sprawę z mechanizmów kierujących użyciem aspektów, należy brać pod uwagę szeroko ujęty kontekst zarówno werbalny, jak i sytuacyjny.

Jednak główny problem korespondencyjnej dyskusji polega na tym, do jakiego poziomu analizy języka przypisuje się asercję. $Z$ tego, co pisze Stanisław Karolak, jednoznacznie wynika, że dla niego asercja należy do sfery semantyki. Wielu badaczy natomiast uważa ją za przejaw pragmatyki językowej.

Wzmiankę o asercji i jej roli w rozróżnieniu aspektów można znaleźć w krótkiej książce Stanisława Karolaka poświęconej aspektowi (Karolak 2005, 98): „Argumentem przeciwko suponowanej identyczności semantycznej członów omawianych par aspektualnych jest to, że jeżeli włożyć je w zasięg asercji, to okaże się, że za pomocą czasowników dokonanych stwierdza się prawdziwość zaistnienia stanu rezultatywnego, a więc prawdziwość konfiguracji inchoatywno-rezultatywnej jako całości, natomiast za pomocą czasowników niedokonanych (zgodnie skądinąd z postulowaną w nich budową semantyczną) tylko prawdziwość procesu, a więc prawdziwość komponentu ciągłego, natomiast komponent inchoatywny/rezultatywny znajduje się poza zasięgiem asercji (jest w zasięgu modalnego predykatu możliwości)”.

Stwierdzenie to i taka analiza członów par aspektowych całkowicie mi odpowiada. To, czego nadal mi brak, to wskazanie na intencje mówiącego, od których zależy wybór formy dokonanej bądź niedokonanej ogólnofaktyw- 
nej czasownika rezultatywnego. Wkroczenie w pragmatykę wydaje mi się tu nieuniknione.

Jednym z problemów, które należałoby tu wyjaśnić, jest rozróżnienie między asercją operującą na poziomie semantyki leksykalnej (wewnątrz znaczenia czasownika) a asercją sfokalizowaną (fokusem) na składnikach zdania, czyli novum. Moja teza jest taka, że obydwa te poziomy nakładają się na siebie przy wyborze aspektu. Tak więc w cytowanym w korespondencji przykładzie:

(10) Ja tego nie niszczyłem (musiał zniszczyć ktoś inny).

fokus skierowany jest na agensa (o czym piszę w mojej odpowiedzi listownej), natomiast $\mathrm{w}$ analogicznym zdaniu $\mathrm{z}$ formą dokonaną czasownika, również dopuszczalnym, które mój rozmówca przytacza jako argument przeciwko proponowanej analizie, fokus obejmuje zarówno agensa, jak i rezultat zawarty w znaczeniu czasownika.

W pracach zajmujących się strukturą informacji używa się rozróżnienia: fokus rozszerzony i fokus ograniczony (Broad and Narrow Focus). Ten ostatni występuje w zdaniach takich jak (10), w których odnosi się tylko do jednego elementu. Fokus rozszerzony natomiast dotyczy porcji zdania składającej się z kilku elementów i stanowiącej informacyjne novum, tak jak w przykładzie (11), gdzie fokus odnosi się do informacji poszedł do kina:

(11) Co zrobił Jan? Jan poszedt do kina.

W najnowszych pracach na temat struktury informacji mowa jest o tym, że fokus (novum) i siła illokucyjna zdania są ze sobą ściśle związane (Haegeman 2002; Frascarelli, Puglielli 2007; Frascarelli 2010), czego autorzy dowodzą na materiale $\mathrm{z}$ różnych języków świata. Badania te zdają się wskazywać na to, iż asercja może być traktowana na jednym poziomie ze strukturą tematyczno-rematyczną zdania.

W rzeczy samej chodzi tu o semantykę wypowiedzenia, czyli mechanizmy dotyczące znaczenia całych zdań. Ale ponieważ zdania, w odróżnieniu od pojedynczych elementów leksykalnych, nie ograniczają się do wyznaczania przedmiotów, sytuacji czy zdarzeń, lecz mają wiele funkcji (wyrażonych przez speech acts) odbijających się na rzeczywistości, w której zachodzi komunikacja, jak również modyfikujących ową rzeczywistość, to być może słuszniej jest umieścić znaczenie wypowiedzenia pod etykietką pragmatyki językowej. Chodzi tu w każdym razie o rozróżnienia operatywne, nie zasadnicze: „nie kłóćmy się o terminologię" - jak pisze Stanisław Karolak w pierwszym z cytowanych listów. 


\section{Literatura}

A u st in J. L., 1963, How to do things with words, Oxford.

Chong T. G., 2003, Russkij glagol'nyj vid skvoz' prizmu rečevych aktov, Moskva.

Frascarelli M., 2010, Narrow Focus, Clefting and Predicate Inversion, „Lingua”, 120, 9: 2121-2147.

Frascarelli M., Puglielli A., 2007, Focus in the Force-Fin System. Information Structure in Cushitic Languages, [w:] Focus Strategies in African Languages. The Interaction of Focus and Grammar in Niger-Congo and Afro-Asiatic, red. E. Oladé Aboh, K. Hartmann, M. Zimmermann, Berlin, s. 161-184.

Geb ert L., 1997, Vzaimozavisimost' meždu značeniem glagola i vidom: sopostavlenije dvuch teorij vida, [w:] „Semantika i struktura slavjanskogo vida” II, red. S. Ka rola k, Kraków, s. $73-86$.

Gebert L., 2004, Fattori pragmatici nella scelta aspettuale, „Studi Italiani di Linguistica Teorica e Applicata" 2, s. 221-232.

$\mathrm{H}$ a e ge $\mathrm{m}$ a $\mathrm{L}$., 2002, Anchoring to speaker adverbial clauses and the structure of CP, „Georgetown University Working Papers in Theoretical Linguistics" 2, s. 117-180.

Is ra eli A., 1996, Discourse analysis of Russian Aspect: Accent on Creativity, „Journal of Slavic Linguistics" 4 (1), s. 8-49.

Ka rolak S., 2005, Semantyka i struktura aspektu w jezykach naturalnych, Kielce.

Ka rcevs ki S., 1927, Système du verbe russe. Essai de linguistique synchronique, Prague.

Kreisberg A., 1997, Vid i pragmatičeskaja perspektiva, [w:] „Semantika i struktura slavjanskogo vida" II, red. S. Ka rola k, Kraków, s. 147-158.

Kreisberg A., 2008, Risultato e conseguenza nella semantica delle predicazioni, „Studi Slavistici” IV, s. 215-235.

Padučeva E. V., 2001, Aspektual'naja specifika glagolov s aktantom rezul'tat: paradoks imperfektiva, „Glossos”, Spring 2001, www.seelrc.org/glossos/issues/1/paducheva.pdf.

Se a rle J. R., 1969, Speech Acts: an Essay in the Philosophy in Language, Cambridge.

Stoll S. E., 2001, The Acquisition of Russian Aspect, PhD. thesis, Berkeley.

Thel in N. (red.), 1999, Verbal Aspect in Discourse, Amsterdam-Philadelphia.

Tow n s end Ch. E., 1985a, Can Aspect Stand Prosperity?, [w:] The Scope of Slavic Aspect, red. M. Flier, A. Timberlake, Columbus, Ohio, s. 286-295.

Townsend Ch. E., 2001, An Approach to Describing and Teaching Slavic Verbal Aspect: Aspect and the Lexicon, „Journal of Slavic Linguistics” 8 (1), s. 171-180. 


\title{
Letters on Aspect
}

\author{
(Summary)
}

The paper presents the correspondence between the author and professor Stanisław Karolak concerning the role of pragmatic factors such as illocutionary force (i. e. an assertion, a negation, an order, a promise ecc.) in perfective/imperfective aspect choice in Russian and Polish.

According to the author's aspect theory, the occurrence of the perfective verb form is determined by illocutionary force that bears on the part of the verb meaning that consists of the change-of-state and its result. That is why, when illocutionary force is focused on other parts of verb meaning, the accomplished facts are expressed by the imperfective.

In his letters Stanisław Karolak expresses a different view: for him assertion is a part of semantics, and he disagrees with taking into consideration pragmatic mechanisms in order to account for aspect variation. 